Frederick C. Gamst (Berkeley). An ethnographic study of the Kemant Agau peoples of Ethiopia (Ethiopia).

G. Wesley Johnson (Columbia). A political history of four communes of Senegal (Senegal, Paris, and the United States).

Willard $R$. Johnson (Harvard). The creation of an integrated political community in the Federal Republic of Cameroun (Harvard).

Raymond K. Kent (Wisconsin). Malgache language and a history of the Malagasy Republic (Paris and the Malagasy Republic).

Martin A. Klein (Chicago). An African society (Paris and Chicago).

Gene A. Maguire (Harvard). The political history of the Sukuma of Tanganyika (Tanganyika, England, and the United States).

David C. Mulford (Oxford). Constitutional change and political parties in Northern Rhodesia, 195 7-64 (England).

Joseph S. Nye (Harvard). Pan-Africanism and unification in East Africa (Harvard).

Mary E. Read (Minnesota). Legal change among the Sukuma in Tanganyika (Tanganyika and England).

John $A$. Rowe (Wisconsin). An historical study of a Buganda political leader in 1875 (Uganda and the United States).

Arnold G. Rubin (Indiana). Jukun arts and their cultural contexts (England, France, and Nigeria).

Satish C. Saberwal (Cornell). Social structure and change among the Embu (Kenya and the United States).

Aaron L. Segal (California). Efforts towards closer union and federation in East Africa (East Africa).

Leo Spitzer (Wisconsin). Multidisciplinary studies relating to South Africa (Wisconsin).

Sidney $R$. Waldron (Columbia). Social change in an urban area in Ethiopia (United States).

Wolfgang O. Weissleder (Chicago). Aspects of traditional Ethiopian society (Europe and Chicago).

Claude Welch (Harvard). Recent attempts at political unification in West Africa (Oxford).

\title{
International African Seminar on the Impact of Christianity in Tropical Africa
}

THE International African Institute is organizing a seminar on the Impact of Christianity in Tropical Africa, to be held from Tuesday, 6 April, to Friday, 16 April I 965, at the University of Ghana, Legon, by courtesy of the Vice-Chancellor. The chairman will be Professor C. G. Baëta, Head of the Department for the Study of Religions at the University of Ghana. The seminar will be the third in a second series of International African Seminars arranged with the aid of a grant from the Ford Foundation.

Papers and discussions will include consideration of the following themes: the introduction of Christianity into Africa in historical perspective; missionary attitudes, methods, relationships, and service; the interaction of Christianity and African life and thought; Christianity in contemporary Africa, including reference to problems of tribalism and race, social change and industrialization, neo-African cultural ideas, and the resurgence of indigenous beliefs and practices. 